\title{
THE PROBLEM OF TEXTBOOKS AS A COMPONENT OF THE FORMATION OF NATURAL EDUCATION
}

\author{
Yana Prystupa \\ Postgraduate Student at the Department of Pedagogy, \\ Kryvyi Rih State Pedagogical University, Ukraine \\ e-mail: access040889@gmail.com,orcid.org/0000-0001-7167-8845
}

\section{Summary}

The modern educational system requires the teacher to form in students certain competencies, choosing a logically structured didactic material. School textbooks play an important role in building competency-based learning. They can actualize students' subjective problems, turn them into cognitive ones, and teach them how to solve them. The analysis of textbooks gives grounds to conclude that the authors, developing textbooks, followed the path of partially adapting them to modern conditions and tasks.

The key features of the textbook's compliance with the formation of individual characteristics of students in the modern educational paradigm are identified, namely: saturation of terminology, headings, saturation of tables and graphs, support for Internet resources. In the process of analyzing the existing textbooks, we also identified the following shortcomings: terms that are too difficult to understand and not logical construction of the material.

Keywords: modern educational paradigm, education, biology, school textbook, formation of competencies, natural competence, methodological principles, New Ukrainian school.

DOI: https://doi.org/10.23856/4908

\section{Introduction}

From time immemorial, the textbook served as a guide for students and was a teacher's assistant on the way to the implementation of the curriculum as a methodological support in explaining the material, and its logical structure and ease of presentation were the key to successful learning. In the conditions of reforming the domestic educational paradigm and integration of education into the European space, the theoretical and didactic support of teaching subjects of the natural cycle on the basis of the competence approach has become relevant. One of the conceptual solutions to this problem was the renewal of curricula, which in the hierarchy of levels of education content correspond to the level of the subject and the presentation within the curriculum of the expected results of students' learning activities in the form of subject competence components. key competencies (Typova osvitnia prohrama zakladiv zahalnoi serednoi osvity III stupenia: nakaz Ministerstva osvity i nauky Ukrainy vid 20.04.2018 № 408.).

In order to implement in the educational process a new approach to the formation of content and planning of textbooks by the authors of the expected results of its assimilation, there is a need to develop relevant didactic tools. Insufficient scientific and methodological validity of the implementation of competency-oriented educational content in school textbooks, including biology, complicates the practical implementation of the competency approach at the level of educational material. The transformation of the educational space caused a number of contradictions, in particular in the vector "implementation of the program competence potential of "Biology" - the content of existing biology textbooks" (Vashchenko, 2015). 


\section{The state of research on the problem of textbooks}

The problem of studying the content and content of the textbook as an integral part in the formation of natural education is in the field of view of scientists and practitioners. Scientific research shows that the solution of this problem has a significant conceptual potential: I. Bekh, I. Zymnya, O. Ovcharuk, O. Pometun, J. Raven, A. Khutorsky emphasized the formation categorical apparatus of the competence approach to learning at different levels of education. Domestic scientists, including N. Bibik, M. Burda, T. Zasekina, O. Lyashenko, O. Savchenko, O. Topuzov, S.Trubacheva and others not only substantiate the content of the textbook relevant at the present stage of development, but also implement their results of scientific research in the author's textbooks and manuals. The functions of the biology textbook, features of its structuring taking into account the competence paradigm are revealed in the works of Ukrainian scientists L.Vashchenko (Vashchenko, 2015), N. Matyash, L.Rybalko, A.Stepanyuk.

Well-known scientist, author of a number of textbooks N. Matyash, notes that the possibilities of the biology textbook in the implementation of innovative approaches to human study is based on the reflection of cognitive, activity and value components of natural competence and didactic functions of cognitive tasks included in the content of her textbooks (Matiash, 2017; Matiash, 2016). Methodological and didactic principles and principles of filling the content of the biology textbook, which are substantiated by A. Stepaniuk and V. Grubinko, serve as a theoretical basis for the project model of the content structure of this textbook (Topuzov, 2014). At the same time, L. Rybalko (Rybalko, 2017) published her own concept of biology textbooks, emphasizing the possibilities of the school textbook "Biology" in the formation of natural competence. It should be noted that the new curriculum in biology (Biolohiia. 6-9 klasy. Prohrama dlia zahalnoosvitnikh navchalnykh zakladiv: metodychni rekomendatsii MON Ukrainy shchodo orhanizatsii navchalnoho protsesu u 2017/2018 navchalnomu rotsi; onovleni na kompetentnisnii osnovi navchalni prohramy dlia 5-9 klasiv; metodychni komentari providnykh naukovtsiv shchodo vprovadzhennia idei Novoi ukrainskoi shkoly, 2017) has clearly identified specific skills that are part of the key competencies that develop in the process of studying biology.

\section{Transformation of the content of textbooks in the context of modern educational reform}

The textbook in the conditions of cardinal-dynamic variability of the subject content of modern education performs a number of functions, in particular as a motivator, an effective means of forming the intellectual and emotional sphere of students, self-control, a tool for diagnosing learning outcomes. This line can be traced by paying attention to one of the subjects of the natural cycle "Natural Science", the content of which is transformed under the influence of the educational reform "New Ukrainian School". The identified key competencies outlined in the NUS concept should not only form a scientific understanding of the modern natural picture of the world and promote the integration of experience into practice, but also teach the application of scientific and empirical methods to analyze and formulate hypotheses, data collection, experiment, conceptual substantiation of results, which is an important component of the modern personality, which today acts as an innovator in the conditions of dynamic changes. (Kontseptsiia Novoi ukrainskoi shkoly).

Analyzing the curriculum in biology, which is studied in primary school, we can say that the obvious focus on the competence potential of the subject helps not only to form a set of key 
competencies for self-realization of individuals. those in the process of development, but also contributes to the development of the ability to adapt to the modern educational dimension. Such a learning outcome is normatively defined and requires the search for ways to achieve it, namely the use of didactic material, in particular the biology textbook. The content of the textbook should correspond to key competencies: synergetic connection of different types of knowledge, subject and general educational skills, attitudes, personal qualities, etc. (Velychko, 2016).

In the context of digitalization, the priority of information in all areas of activity is a leading feature, so the formation of competencies is possible, in our opinion, by means of the author's textbook of biology. It is important then to create conditions for the effective adaptation of the individual to the continuous expansion of the information space, the rapid mastery of new ways of obtaining, processing and disseminating information. In the program "Biology" (for grades 6-9, 2017), information and digital competence involves the confident but critical use of information and communication technologies (ICT) for the creation, retrieval, processing, exchange of information at work, in public space and private communication. Information and media literacy, basics of programming, algorithmic thinking, working with databases, Internet and cyber security skills. Understanding the ethics of working with information (copyright, intellectual property, etc.) "(Biolohiia. 6-9 klasy. Prohrama dlia zahalnoosvitnikh navchalnykh zakladiv: metodychni rekomendatsii MON Ukrainy shchodo orhanizatsii navchalnoho protsesu u 2017/2018 navchalnomu rotsi; onovleni na kompetentnisnii osnovi navchalni prohramy dlia 5-9 klasiv; metodychni komentari providnykh naukovtsiv shchodo vprovadzhennia idei Novoi ukrainskoi shkoly, 2017). The textbook directs students to the systematic use of Internet resources in order to comprehensively study all living things at different levels of life, using innovative methods.

For example, to acquaint students with modern methods of studying genetics and evolutionary biology will help knowledge of bioinformatics, the main direction of which is sequence alignment, gene search, genome assembly, alignment of protein structures, prediction of protein structure, prediction of gene expression and reconstruction of evolution using computer algorithms and statistical methods for analysis (Topuzov, 2014). Students will learn what large segments of non-coding eukaryotic DNA look like, which scientists work in the field of genetics and selection, identify areas of scientific and practical application of bioinformatics to determine the DNA sequence for protein identification.

The topic "Ecosystem level of life organization", which completes the study of biology in primary school, is supplemented by information on innovative technologies for monitoring the ecological status of ecosystems. An example of a computer model of ecosystem balance components demonstrates to students the effectiveness of the modeling method in studying the distribution of light energy in the ecosystem, the growth of trees, shrubs and grasses, the process of mineralization and soil erosion using ICT. On the pages of the textbook "Biology 9th grade" (S. Mezhzherin, new program) students are motivated to try to create their own information product, ie ecosystem models, presentation, project and more. The content of the textbook with graphs of various types, diagrams, charts, tables, contribute to the expansion of the scientific worldview in terms of methods of recording and forms of reporting on the results of bioexperiments (Korshevniuk, 2017; Mezhzherin, Mezherina, 2017).

In the conditions of modern educational paradigm, among other competencies, no less important is initiative and entrepreneurship, which is realized in the textbook "Biology 9th grade" R. Shalamova and others. through not only the implementation of achievements in biology and related sciences, but also the incorporation of prospects for further research into biosystem diversity, conservation and efficient use of natural resources, forecasting and monitoring the impact of biological science on the iteration of innovative technologies (Shalamov, 2017). 
The key tasks of natural education, including biology, geography, ecology, are the education of its components - to teach to assess the positive potential and identify risks of using biological benefits for humans, to develop civic consciousness of the younger generation, to educate the environment and to initiate environmental measures. personal responsibility. To do this, Shalamov's textbook has a section "Find out for yourself and tell others", which contains specific tasks, such as processing additional sources of information and answering the question of determining the main anthropogenic changes in the ecology of your region and the consequences of these changes (Shalamov, 2017). Another example of such an educational conglomerate is the organization of the student's work in the spectrum of identifying their own abilities and determining the scope of their benefits. Thus, in the 6th grade geography textbook in the section "Work in a group" it is proposed to study the issues of waste disposal in their areas and offer their ways, embodying their proposals in the mini-project "Waste - in income", thus creating such conditions for students. which they can demonstrate the results of their own research, feel their significance and satisfaction from their work and communication in the team, which is an important activity of this age group.

Qualitative natural training of students will promote the development of skills to solve educational problems and apply them both in the process of studying the disciplines of the natural cycle, and implement them in practice. Therefore, in the textbook it is important to pay attention to the task in order to practically apply knowledge of natural sciences, which will contribute to the understanding of educational material, development of critical thinking, logic and other important personality traits in the mainstream educational space. Such a tool in the textbook "Biology and Ecology" 10th grade is the rubric "Think!", Which has a clear task to explain why it is important for a person to know the process of metabolism, recalling the information of the previous lesson (Sobol, 2018); Cross-cutting content lines in the course "Ukraine in the World: Nature, Population" for 8th grade students are also focused on "Environmental Safety and Sustainable Development" as an integral part of shaping the student's personality as an innovator, referring to modeling situations (rules of conduct in emergencies, orienteering, etc.). These types of tasks motivate to replenish the treasury of life experience and help to realize the importance of their own knowledge, which is necessary in the process of forming the ability to learn throughout life as one of the leading competencies (Puhach, 2016).

In order to form competence in the development of communication skills in foreign languages, the content of school natural education is saturated with terms of foreign origin, the assimilation of which contributes, according to the current State standard of basic and complete general secondary education, mastery of the conceptual apparatus of natural sciences. The textbook also contains a wide range of information sources of natural content about international research programs and projects: the World Society for the Protection of Animals (WSPA), the Global Ecolabeling Network (GEN). kind of concepts in the field of natural sciences are a demonstration of the integration of natural sciences in various spheres of social activity (Derzhavnyi standart bazovoi i povnoi zahalnoi serednoi osvity 2011 (Postanova Kabinetu Ministriv Ukrainy) № 1392).

The expansion of the scope of application of genetically modified organisms necessitates the acquaintance of schoolchildren in the learning process with both methods of obtaining GMOs and the implementation of analytical generalization, appealing to bioethics. The process of incorporating transgenic plants into the production of "edible vaccines", creating plants adapted to pests, and more is very important.

Natural education, in particular biology, is under the influence of anthropogenic factors while penetrating deeply into all spheres of life of modern man, which is taken into account during the 
formation of the content of an applied nature. This trend increases the role of the value approach in the context of assessing the prospects for the development of biology and its use in practice. This is reflected in the pages of the textbook in the context of socio-ethical issues related to the study of wildlife: when considering the possible impact of GMOs on the human body and other biosystems, regulation under current legislation of the use of such organisms in terms of biosafety.

Another example in the study of "Zoology" and "Human Biology" is the formation of the student's attitude to the problem of using animals in experiments, forecasting the consequences and ways to prevent mutagens from entering the environment. It is a common fact that project activities are an effective means of forming competencies, so the textbook contains markers for the implementation of the curriculum, projects indicating possible resources, advice on the organization of activities and forms of presentation of results. At the same time, a possible plan of work on the project with the possibility of writing one's own plan is given - all this has a recommendatory character for the development of the student's individuality, without limiting initiative and creativity (Biolohiia i ekolohiia 6-11 klasy navchalni prohramy metodychni rekomendatsii u 2019/2020 n. r./ uklad. Fitsailo, 2019).

\section{Conclusions}

In the conditions of modern educational space the logical construction and content of any methodical literature is a means of effective formation of key competencies in the conditions of reforming the New Ukrainian school. In this context, the textbook is one of the leading assistants for both the teacher in explaining the material and checking its conscious assimilation through the prism of the versatility of the functions it performs, and for students as an accessible guide to understanding the modern scientific world. Author's textbooks, which have been compiled taking into account the current legislation, in particular, take into account the recommendations of the State Standard of Basic and Secondary Education, are becoming relevant. Markers of relevance of the textbook on the way of forming individual features of students as innovators in the educational reality are: saturation of terminological apparatus, which serves as a basis for studying disciplines of natural cycle, rubrics that appeal to life experience and can provide basic principles of its application in order to form an empirical awareness of educational material, support of Internet resources, which is important in the context of global digitalization. Instead, the main disadvantages of modern biology textbooks are: terms that are too difficult to understand and not logical construction of the material (for example, "Human Biology" in 9th grade).

In our opinion, it is necessary to simplify the terminology and content of the textbook.

We consider the prospects of further research to determine the degree of detail and development of means of realization of the competence potential of the content of biological education for basic secondary and specialized secondary school.

\section{References}

1. Biolohiia. 6-9 klasy. Prohrama dlia zahalnoosvitnikh navchalnykh zakladiv: metodychni rekomendatsii MON Ukrainy shchodo orhanizatsii navchalnoho protsesu $u$ 2017/2018 navchalnomu rotsi; onovleni na kompetentnisnii osnovi navchalni prohramy dlia 5-9 klasiv; metodychni komentari providnykh naukovtsiv shchodo vprovadzhennia idei Novoi ukrainskoi shkoly (2017). [ Biology. Grades 6-9. Program for secondary schools: methodological recommendations of the Ministry of Education and Science of Ukraine on the organization 
of the educational process in the 2017/2018 academic year; updated competency-based curricula for grades 5-9; methodical comments of leading scientists on the implementation of the ideas of the New Ukrainian School]. Kyiv: UOVTs «Orion». [in Ukrainian]

2. Biolohiia i ekolohiia 6-11 klasy navchalni prohramy metodychni rekomendatsii u 2019/2020 n. r./ uklad. Fitsailo S. (2019). [Biology and ecology 6-11 classes curricula methodical recommendations in 2019/2020 n. p. / way. Fitsaylo S.] Kyiv: Ranok. [in Ukrainian]

3. Vashchenko L.S. (2015). Rol pidruchnykiv biolohii u formuvanni predmetnykh kompetentnostei. [The role of biology textbooks in the formation of subject competencies]. Problemy suchasnoho pidruchnyka (15), 97-105. [in Ukrainian]

4. Velychko L. P. (2016). Kalendarno-tematychne planuvannia z biolohii i khimii na osnovi kompetentnisnoho pidkhodu. Biolohiia i khimiia v ridnii shkoli (4), 2-5. [Calendar-thematic planning in biology and chemistry based on the competency approach. Biology and chemistry in the native school.]. [in Ukrainian].

5. Derzhavnyi standart bazovoi i povnoi zahalnoi serednoi osvity 2011 (Postanova Kabinetu Ministriv Ukrainy) № 1392. [State standard of basic and complete general secondary education: Resolution of the Cabinet of Ministers of Ukraine].[in Ukrainian].

6. URL: https://zakon.rada.gov.ua/laws/show/1392-2011-\%D0\%BF\#Text

7. Kontseptsiia Novoi ukrainskoi shkoly. URL: https://mon.gov.ua/storage/app/media/zagalna\%20 serednya/nova-ukrainska-shkola-compressed.pdf (Data zvernennia 21.09.2021) ].[in Ukrainian].

8. Korshevniuk T.V. (2017). Biolohiia: pidruch. dlia $9 \mathrm{kl}$. zahalnoosvit. navch. zakladiv. [Biology: textbook. for 9 classes. general education. textbook institutions.]. Kyiv: UOVTs «Orion».[in Ukrainian].

9. Matiash N. (2016). Systema zavdan u pidruchnykakh z biolohii yak zasib formuvannia $v$ uchniv predmetnoi kompetentnosti. Problemy suchasnoho pidruchnyka. (16), 212-223. [The system of tasks in biology textbooks as a means of forming students' subject competence. Problems of a modern textbook.][in Ukrainian].

10. Matiash N.Iu. (2017). Vidobrazhennia kompetentnisnoho pidkhodu do vyvchennia liudyny $v$ avtorskykh pidruchnykakh z biolohii. Problemy suchasnoho pidruchnyka.(18),88-95. [Reflection of the competence approach to the study of man in the author's textbooks in biology. Problems of a modern textbook.][in Ukrainian].

11. Mezhzherin S.V., Mezherina Ya.O. (2017). Biolohiia: pidruchnyk dlia 9 klasu zahalnoosvitnikh navchalnykh zakladiv. [Biology: a textbook for 9th grade secondary schools.] Ternopil: Pidruchnyky ta posibnyky.[in Ukrainian].

12. Puhach M.I. (2016). Ukraina u sviti: pryroda, naselennia. Praktykum. 8 klas. [Ukraine in the world: nature, population. Workshop. 8th grade]. Ternopil: Bohdan.[in Ukrainian].

13. Rybalko L.M. (2017). Avtorska kontseptsiia pidruchnykiv z biolohii na zasadakh kompetentnisnoho pidkhodu do navchannia. Problemy suchasnoho pidruchnyka.(18), 192-199. [Author's concept of textbooks in biology on the basis of a competency-based approach to learning. Problems of a modern textbook] [in Ukrainian].

14. Sobol V. I. (2018). Biolohiia i ekolohiia (riven standartu): pidruch. dlia 10 kl. zakl. zah. sered. Osvity. [Biology and Ecology (standard level): textbook. for 10 classes. lock head among. Education.]. Kamianets-Podilskyi: Abetka.[in Ukrainian].

15. Typova osvitnia prohrama zakladiv zahalnoi serednoi osvity III stupenia: nakaz Ministerstva osvity i nauky Ukrainy vid 20.04.2018 № 408. URL: https://mon.gov.ua/ua/osvita/zagalna-serednya-osvita/navchalni-programi/tipovi-osvitni-programi-dlya-2-11-klasiv ].[in Ukrainian].

16. Topuzov O. M. (2014). Dydaktychna prohnostyka v konteksti teoretyko-metodychnoho zabezpechennia stvorennia suchasnoho pidruchnyka. Problemy shkilnoho pidruchnyka : zb. nauk. prats / za holov. red. O. M. Topuzova. [Didactic prognosis in the context of theoretical and methodological support for the creation of a modern textbook.]Kyiv: Pedahohichna dumka [in Ukrainian].

17. Shalamov R.V. (2017). Biolohiia: pidruchnyk dlia 9 klasu zahalnoosvitnikh navchalnykh zakladiv.[ Biology: a textbookfor 9th grade secondary schools.] Kharkiv: Soniashnyk.[in Ukrainian]. 